\title{
Reimagining Civil Engineer's Managerial Role as an Entrepreneurial Function in the Production System of a Construction Project
}

\author{
Christie Lanjing Entika, ${ }^{1, *}$, Shahrin Mohammad ${ }^{1}$, Mohd Khata Jabor ${ }^{2}$, Sharifah Osman² \\ ${ }^{1}$ School of Civil Engineering, Faculty of Engineering, Universiti Teknologi Malaysia, Johor, Malaysia \\ ${ }^{2}$ School of Education, Faculty of Social Sciences and Humanities, Universiti Teknologi Malaysia, Johor, Malaysia
}

Received March 16, 2020; Revised May 12, 2020; Accepted May 20, 2020

Copyright $\odot 2020$ by authors, all rights reserved. Authors agree that this article remains permanently open access under the terms of the Creative Commons Attribution License 4.0 International License

\begin{abstract}
Civil engineers have been reported to work more in the management aspect of a construction project. As such, civil engineers commonly play their roles predominantly under the managerial perspective. Interestingly, building and construction industry is a combination of manufacturing and service industry which offer opportunity to view the managerial role played by civil engineers from the perspective of the theory of Marshallian entrepreneur. This perspective enables one to re-imagine the managerial role played by civil engineers as an entrepreneurial function. In this perspective, civil engineer who plays the managerial role is being assumed as the one who takes up the Marshallian entrepreneur's function and the managerial role which exhibits all of the elements of the Marshallian entrepreneur's function is the managerial role that demonstrates the epitome of entrepreneurial function in the production system of a construction project. Based on the identification of the elements of Marshallian entrepreneur's function, it can be seen that an evolved civil engineer's managerial role demonstrates the epitome of entrepreneurial function. The evolved civil engineer's managerial role exhibits the element of deciding what product can be produced to satisfy human needs which differentiate it from the conventional managerial role and this element offers opportunity for civil engineer to embrace entrepreneurial orientation. As this element in the context of construction project is yet to be fully understood, further research is needed for future civil engineering practices. In terms of civil engineering education, re-imagining civil engineer's managerial role as an entrepreneurial function highlights the need to introduce entrepreneurial orientation to future civil engineering graduates.
\end{abstract}

Keywords Re-imagining, Civil Engineer, Managerial Role, Entrepreneurial Function, Strategic Orientation

\section{Introduction}

Civil engineers have been reported to work more in the management aspect of a construction project where managing construction projects and business contract and working with both public and private sectors are the managerial roles played by civil engineers (Grigg, et. al, 2001). As such, civil engineers commonly play their roles predominantly under the managerial perspective. Interestingly, building and construction industry is a combination of manufacturing industry (materials, components, equipment) and service industry (engineering, design, surveying, consulting, and management) (Blayse and Manley, 2004). The combinations of these industries that make up the building and construction industry are offering an opportunity to view the managerial role played by the civil engineers from a different perspective.

The different perspective that the authors adopted was drawn from the perspectives of entrepreneurship theory. In this regard, it is important to highlight that there are diverse perspectives of entrepreneurship (Entika et. al, 2018). Therefore, in this paper, the specific entrepreneurship perspective that the authors have adopted is known as the theory of Marshallian entrepreneur. This perspective enables one to re-imagine the managerial role played by civil engineers as an entrepreneurial function (Veciana, 2007) and it could shed some light on the opportunity for civil engineers to embrace entrepreneurial orientation in their practice. Embracing entrepreneurial orientation will require civil engineers to use strategic orientation in their firm which captured specific entrepreneurial aspects of decision-making styles, methods, and practices (Wiklund and Shepherd, 2005). According to Dess and Lumpkin 
(2005), entrepreneurial orientation is deemed necessary in engaging successful corporate entrepreneurship and has been found of having strong influence in the growth of the construction enterprises (Abd-Hamid, Azizan and Sorooshian, 2015).

\section{The Trend, Paradigm and Change in Civil Engineer's Managerial Role}

Traditionally, civil engineers' role in any construction projects is concentrated mainly in the technical aspects of a construction project (Grigg et. al., 2001). Nevertheless the expansion of civil engineers' role beyond the technical aspect can be noticed as early as in the 1980s as there is a conjecture that civil engineers have a pertinent role in urban planning and development (Lyles, 1984). Thereafter, the role of civil engineers has continued to expand with the modernisation of basic public needs and caused the emergent of a range of diverse role which is mainly within the interplay of technical roles (design, construction, implementation) and managerial roles (planner, administrative, legal, financial). The trend of such role played by civil engineers is commonly reported in literature as shown in Table 1.

Although the diverse role played by civil engineers is mainly within the interplay of technical and managerial roles, it can be seen that the trend of the civil engineers role tend to incline more towards the managerial aspect regardless of the types of construction project that they are involved in. This trend has not changed much over the decades despite the rapid advancement of construction projects such as the construction project of smart infrastructure and thus highlighted the significance of civil engineers' managerial role in a construction project.

According to Grigg et. al. (2001), the general function of the civil engineers' managerial role is to manage the 'input-output processes' in the production system of a construction project as shown in Figure 1.

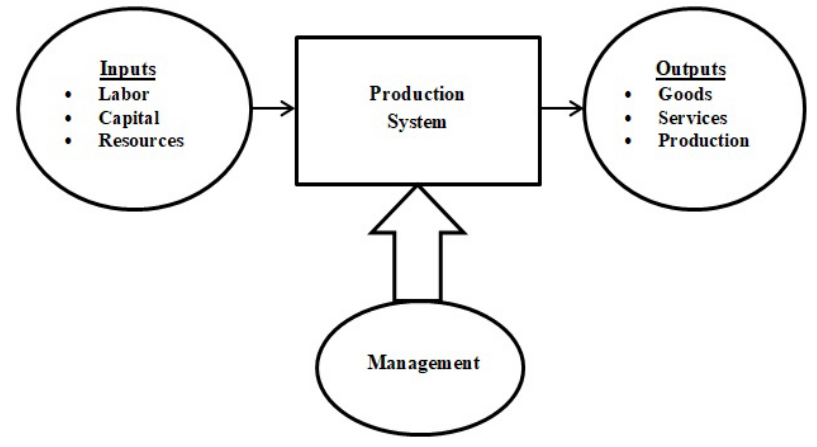

Figure 1. The production system of a construction project (Grigg, et. al, 2001)

Table 1. The trend of diverse role played by civil engineers

\begin{tabular}{|c|c|c|}
\hline Author(s) & Civil Engineer's Role & Project \\
\hline Lyles (1984) & Planner & Urban planning and development \\
\hline Hoften (1988) & $\begin{array}{c}\text { Design and construction ground facilities for the launch platforms, } \\
\text { rocket engine testing, and transportation infrastructure of manned and } \\
\text { unmanned flights }\end{array}$ & $\begin{array}{l}\text { Infrastructure related project and } \\
\text { engine testing for aerospace } \\
\text { projects }\end{array}$ \\
\hline $\begin{array}{l}\text { Perez and Ardaman } \\
(1988)\end{array}$ & $\begin{array}{c}\text { Involve in administrative, legal, financial and political issues, in } \\
\text { addition to traditional technical function }\end{array}$ & $\begin{array}{l}\text { Infrastructure related projects to } \\
\text { serve public needs }\end{array}$ \\
\hline $\begin{array}{c}\text { Corotis and Scanlan } \\
(\mathbf{1 9 8 9 )} \\
\end{array}$ & $\begin{array}{c}\text { Advancing the basic needs of society such as shelter, sanitation, } \\
\text { transportation, clean water and others }\end{array}$ & $\begin{array}{c}\text { Infrastructure related projects for } \\
\text { public needs }\end{array}$ \\
\hline Fell (1990) & Planner, Site investigator & Geotechnical projects \\
\hline Toole (2005) & Design engineer & Safety and health for any projects \\
\hline $\begin{array}{c}\text { Gambatese, Behm and } \\
\text { Rajendran (2008) }\end{array}$ & Project designer and planner & Safety and health for any projects \\
\hline Head (2009) & $\begin{array}{l}\text { Design and implement required new infrastructure system for } \\
\text { sustainable outcomes }\end{array}$ & Infrastructure related projects \\
\hline Watts (2009) & $\begin{array}{l}\text { Technical and Managerial roles include report- writing, bid } \\
\text { preparation, computer modelling, laboratory and site work and client } \\
\text { liaison }\end{array}$ & $\begin{array}{c}\text { Infrastructure, building } \\
\text { construction, utility construction } \\
\text { and energy plants } \\
\end{array}$ \\
\hline Goh and Chua (2015) & Designing projects for Safety & Safety and health for any projects \\
\hline Rogers et. al, (2017) & $\begin{array}{l}\text { Managing and Planning usage of materials for construction projects } \\
\text { for concern of resource scarcity and security }\end{array}$ & Any projects \\
\hline Berglund et. al., (2020) & $\begin{array}{l}\text { Master planner, designer, constructor and operator of the built } \\
\text { environment; steward of natural environment and its resources; } \\
\text { innovator and integrator of ideas and technology across the public, } \\
\text { private and academic sectors; manager of risk and uncertainty; and } \\
\text { leader in discussions and decisions shaping public environmental } \\
\text { and infrastructure policy }\end{array}$ & $\begin{array}{l}\text { Smart infrastructure related } \\
\text { projects }\end{array}$ \\
\hline
\end{tabular}

* words in bold indicate civil engineers' role 


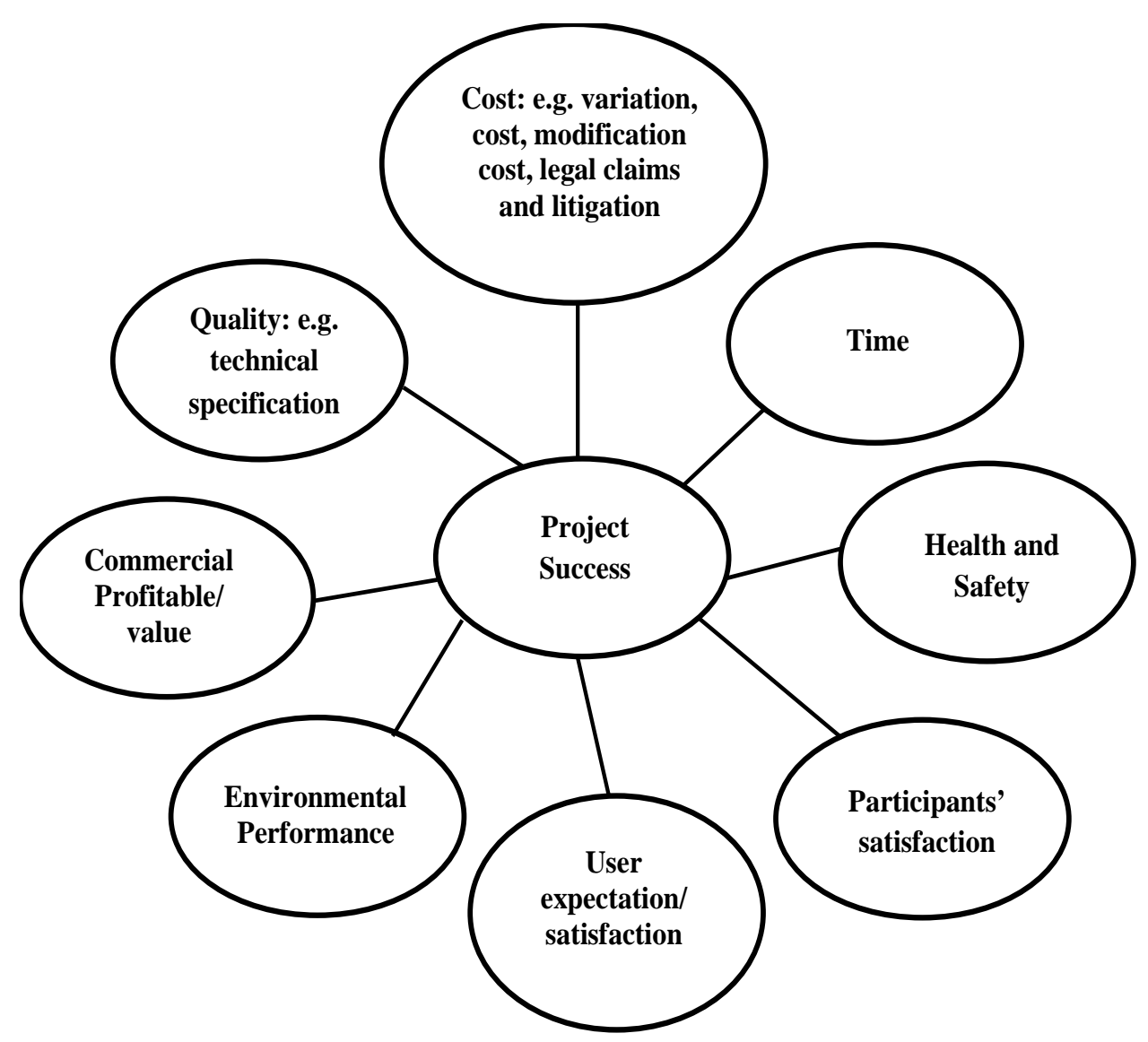

Figure 2. Consolidated Framework for measuring success of construction projects (Chan and Chan, 2004)

Managing the 'input-output processes' is a daunting task as civil engineers are expected to produce a unique product based on stringent cost, schedule and quality (Hensen and Zenobia, 2011). Furthermore, the product of a construction project is only considered successful when it fulfills certain criteria of success. According to the framework proposed by Chan and Chan (2004), a construction project is considered successful when it fulfills the eight consolidated criteria as shown in Figure 2.

The criteria for measuring success as shown in Figure 2 is addressing the different areas of concern in a construction project which highlighted the challenges that could affect the 'input-output processes' of the production system. Taking into account the various areas of concern in a construction project and considering the view of the project management paradigm (which is based on organisation theory), it has been proposed that a construction project can be likened to an organisation and the project manager role (or managerial role) played by the civil engineer is perceived similar to the role play by a chief operating officer (COO) of a company (Anderson, 1992). In this paradigm, the operation of the construction project relies heavily on the expertise of the civil engineer who plays managerial role in the production system of a construction project (Hodgson, Paton and Cicmil, 2011).
Nevertheless, due to the growing complexities of issues related to construction industry that requires civil engineers to balance economic, social and environmental considerations (Rogers et. al, 2017), the perception that a construction project is being likened to an organisation is likely to fall short from being able to address the dynamic need of the managerial role to response quickly to the emerging issues. As a result, managerial role played by the civil engineers has evolved into a multifaceted role in order to be effective in responding to emerging issues. Edum-Fotwe and McCaffer (2000), suggested that the multifaceted role of civil engineers' managerial role includes playing the role of an entrepreneur or strategist who provides innovative solutions for both product and business processes, a manager who oversees the general function of the construction, a production engineer who manages effective implementation of the project and a technological innovator who leverages on the use of technology for competitive advantage. The evolvement of civil engineers' managerial role into a multifaceted role indicates the need to look into the civil engineers' managerial role from a different perspective than the perspective of project management paradigm which is based on the organisation theory. In this paper, the different perspective is viewed from the lens of the theory of Marshallian entrepreneur. 


\section{The Perspective of Theory of Marshallian Entrepreneur}

The theory of Marshallian entrepreneur proposed that the entrepreneur's function was centralised in the role of an organiser or coordinator who increases production efficiency by means of economising resources and using new arrangement (Karayiannis, 2009). The organiser or coordinator economises resources and makes new arrangement by coordinating capital and labors within the entrepreneur's firm, driving the production and distribution of process, coordinating supply and demand in the market, undertaking risk associated with the production, minimizing cost of production, and innovates (Van Praag, 1999). In a more comprehensive way, Marshallian entrepreneur's function can be synthesised into the following functions;

1. Deciding what product to produce to satisfy human needs

2. Deciding on and acquire the necessary means of production (material means, capital, and labor)

3. Establishing the general production plan or to decide on the optimal combination of the production factors

4. Managing the whole production and marketing process

5. Undertaking the risks associated with this process (Veciana, 2007).

The context of the theory of Marshallian entrepreneur was understood to be dating back to the era of British industrial revolution where the widespread of mechanisation in manufacturing occurred and entrepreneurial sphere was recognised as a function of production (Stokey, 2001). In such context, the importance of the entrepreneur's function as the organiser of the production of good and services in the industry was significant (Veciana, 2007). Hence, on the basis of the significance of the entrepreneur's function as the organiser of the production of good and services, the main role of entrepreneurship was argued to be similar to organising and managing a firm and such function was seen as the center of the industry (Karayiannis, 2009). For that reason, it was being pointed out that the theory of Marshallian entrepreneur belongs to the neoclassical school of economic theorists in which entrepreneurial sphere as a function of production was being recognised (Cuevas, 1994).

According to Karayiannis (2009), the theory of Marshallian entrepreneur has been argued to be the first proposal that analytically advanced adequate entrepreneurial theory that covers multidisciplinary factors and elements. The multidisciplinary factors and elements covered by the theory of Marshallian entrepreneur enabled the theory to be applied in fields other than the economic field although it belongs to the neoclassical school of economic theorists. The application of the theory of the Marshallian entrepreneur in other field is based on the theoretical approach demonstrated in the entrepreneurial function of the theory of Marshallian entrepreneur (Veciana, 2007).

In view of the theoretical approach demonstrated in the entrepreneurial function of the theory of Marshallian entrepreneur, the authors propose that a civil engineer's managerial role that exhibits all of the elements of the Marshallian entrepreneur's function is to be considered as the managerial role that demonstrates the epitome of entrepreneurial function in the production system of a construction project. Therefore, in this paper the elements of the Marshallian entrepreneur's function are serving as the criteria in deciding the suitability of the managerial role to be re-imagined as an entrepreneurial function.

\section{Re-imagining Managerial Role as an Entrepreneurial Function}

In order to re-imagine the managerial roles played by civil engineers as an entrepreneurial function, it is assumed that the civil engineer who plays the managerial role takes up the function of the Marshallian entrepreneur as synthesised by Veciana (2007). On this basis, any managerial role played by a civil engineer that exhibits every element of the Marshallian entrepreneur's function is considered as the suitable managerial role that can be re-imagined as an entrepreneurial function. Therefore, to recognise the suitable managerial role, the elements of the Marshallian entrepreneur's function in the managerial role reported in literature are being identified. As there are limited types of civil engineer's managerial role being reported in literature, 2 types of civil engineer's managerial role were selected. For the purpose of this paper, both types of managerial role that are being considered are not with respect to unique context rather both are with respect to general context in construction. The selected civil engineer's managerial roles are the conventional civil engineer's managerial role reported by Grigg et. al. (2001), the evolved civil engineer's managerial role reported by Edum-Fotwe and McCaffer (2000). Both types of civil engineer's managerial role are reported to be with respect to any construction projects. The identification of the Marshallian entrepreneur's function was based on the entrepreneurial function synthesised by Veciana (2007).

The recognition of suitable managerial role was conducted first on the conventional civil engineer's managerial role. The civil engineer's managerial role reported by Grigg et. al. (2001) can be considered as conventional managerial role because the civil engineering practices reported by Grigg et. al. (2001) is pointed out to consist of 2 tracks, that is the technical track or the management track which is how civil engineering practices is being conventionally understood. According to the 
conventional civil engineer's managerial role reported by Grigg et. al. (2001), there are 7 categories of activities involved in the managerial role. By considering the 7 categories of activities involved in the managerial role and the elements of the Marshallian entrepreneur's function synthesised by Veciana (2007), the presence of the elements of the Marshallian entrepreneur's function in the conventional managerial role can be identified. The identification of the elements of the Marshallian entrepreneur's function enables a clear observation of whether the conventional civil engineer's managerial role is suitable to be re-imagined as an entrepreneurial function. Table 2 shows the identification of the function of Marshallian's entrepreneur in civil engineer's managerial role reported by Grigg et. al. (2001).

As can be seen in Table 2, the elements of the Marshallian entrepreneur's function are particularly absent in 3 activities of the conventional civil engineer's managerial role reported by Grigg et. al. (2001). The activities that do not exhibit the elements of the Marshallian entrepreneur's function are the activities related to public organisational management, environmental regulation and program management. Besides that, the element of deciding what product to produce to satisfy human needs is noticeably absent from any activities in the conventional civil engineer's managerial role. Although one may argue that the business management activities of the conventional civil engineer's role may concern the civil engineer's decision on what product to produce to satisfy human needs, nevertheless, the business management activities is within the taxonomy work of business development and marketing (Grigg et. al.,2001), rather than specifically deciding on what product to produce to satisfy human needs. Therefore, the conventional managerial role can be deemed as not the suitable managerial role that can be re-imagined as an entrepreneurial function.

Table 2. Identification of the Marshallian Entrepreneur's Function in the Evolved Civil Engineer's Managerial Role

\begin{tabular}{|c|c|c|c|c|c|}
\hline $\begin{array}{l}\text { Conventional civil } \\
\text { engineer's } \\
\text { managerial activities } \\
\text { Grigg et. al. (2001) }\end{array}$ & $\begin{array}{c}\text { Deciding } \\
\text { what product } \\
\text { to produce to } \\
\text { satisfy } \\
\text { human needs }\end{array}$ & $\begin{array}{l}\text { Deciding on and } \\
\text { acquire the } \\
\text { necessary means of } \\
\text { production } \\
\text { (material means, } \\
\text { capital, and labour) }\end{array}$ & $\begin{array}{l}\text { Establishing the } \\
\text { general } \\
\text { production plan } \\
\text { or to decide on } \\
\text { the optimal } \\
\text { combination of } \\
\text { the production } \\
\text { factors }\end{array}$ & $\begin{array}{c}\text { Managing } \\
\text { the whole } \\
\text { production } \\
\text { and } \\
\text { marketing } \\
\text { process }\end{array}$ & $\begin{array}{l}\text { Undertaking } \\
\text { the risks } \\
\text { associated } \\
\text { with this } \\
\text { process }\end{array}$ \\
\hline $\begin{array}{l}\text { (1) Project Management } \\
\text { focus on specific system using } \\
\text { resources, people, team members, } \\
\text { contracts }\end{array}$ & & $\sqrt{ }$ & $\sqrt{ }$ & $\sqrt{ }$ & \\
\hline $\begin{array}{l}\text { (2) Business Management } \\
\text { - } \quad \text { all aspects of private business } \\
\text { management, including consulting firms }\end{array}$ & & & & $\sqrt{ }$ & $\sqrt{ }$ \\
\hline $\begin{array}{l}\text { (3) Public Organizational Management } \\
\text { - City or agency management, public } \\
\text { works management }\end{array}$ & & & & & \\
\hline $\begin{array}{l}\text { (4) Operation Management } \\
\text { managing ongoing situations and } \\
\text { systems }\end{array}$ & & & & $\sqrt{ }$ & \\
\hline $\begin{array}{l}\text { (5) Human Resource Management } \\
\text { - administrative or supervision }\end{array}$ & & & & $\sqrt{ }$ & \\
\hline $\begin{array}{l}\text { (6) Environmental Regulation } \\
\bullet \quad \begin{array}{l}\text { decision making on how to regulate in } \\
\text { environmental arena }\end{array} \\
\end{array}$ & & & & & \\
\hline $\begin{array}{l}\text { (7) Program management } \\
\text { - developing and offering a program, such } \\
\text { as an outreach program or service } \\
\text { operation }\end{array}$ & & & & & \\
\hline
\end{tabular}

*The highlighted rows are areas in the managerial activities that do not exhibit any element of Marshallian entrepreneur's function and the highlighted column is the element of Marshallian entrepreneur's function that is absent from any managerial activities. 
Table 3. Identification of the Marshallian Entrepreneur's Function in the Evolved Civil Engineer's Managerial Role

\begin{tabular}{|c|c|c|c|c|c|}
\hline $\begin{array}{l}\text { Evolved civil } \\
\text { engineer's } \\
\text { managerial role } \\
\text { (Edum-Fotwe and McCaffer,2000) }\end{array}$ & $\begin{array}{l}\text { Deciding } \\
\text { what product } \\
\text { to produce to } \\
\text { satisfy } \\
\text { human needs }\end{array}$ & $\begin{array}{l}\text { Deciding on and } \\
\text { acquire the } \\
\text { necessary means } \\
\text { of production } \\
\text { (material means, } \\
\text { capital, and labour) }\end{array}$ & $\begin{array}{l}\text { Establishing the } \\
\text { general } \\
\text { production plan } \\
\text { or to decide on } \\
\text { the optimal } \\
\text { combination of } \\
\text { the production } \\
\text { factors }\end{array}$ & $\begin{array}{l}\text { Managing } \\
\text { the whole } \\
\text { production } \\
\text { and } \\
\text { marketing } \\
\text { process }\end{array}$ & $\begin{array}{l}\text { Undertaking } \\
\text { the risks } \\
\text { associated } \\
\text { with this } \\
\text { process }\end{array}$ \\
\hline $\begin{array}{l}\text { Strategist/Entrepreneur (External Focus) } \\
\text { - customer focus, product innovation, } \\
\text { analytical ability, risk management, } \\
\text { business }\end{array}$ & $\sqrt{ }$ & & $\sqrt{ }$ & $\sqrt{ }$ & $\sqrt{ }$ \\
\hline $\begin{array}{l}\text { Technology Innovator } \\
\bullet \quad \text { process efficiency, product } \\
\quad \text { effectiveness, technical innovation }\end{array}$ & $\sqrt{ }$ & & $\sqrt{ }$ & & \\
\hline $\begin{array}{l}\text { Production engineer } \\
\text { - } \quad \text { technical design, technical supervision, } \\
\text { material allocation \& scheduling, quality } \\
\text { assurance }\end{array}$ & & $\sqrt{ }$ & $\sqrt{ }$ & $\sqrt{ }$ & \\
\hline $\begin{array}{l}\text { Manager (Internal focus) } \\
\text { people, resources, change, } \\
\text { communication, organisational } \\
\text { relationships, team builder, coordinator } \\
\text { and leader }\end{array}$ & & $\sqrt{ }$ & $\sqrt{ }$ & $\sqrt{ }$ & \\
\hline
\end{tabular}

The second type of managerial role is believed to be the evolved version of civil engineer's managerial role reported by Edum-Fotwe and McCaffer (2000). The evolved civil engineer's managerial role originated from the perspective of combining skills needed in solving problem which can be technical, managerial and interpersonal in nature, with the traditional engineering knowledge (Edum-Fotwe and McCaffer, 2000). This perspective enables the civil engineer's managerial role to have double edge focus where both external and internal factors are being taken into account. Based on key areas in modern project management, civil engineer in their evolved managerial role is believed to function as a strategist or an entrepreneur, technology innovator and production engineer in addition to functioning as a manager (Edum-Fotwe and McCaffer, 2000). By identifying the presence of the elements of the Marshallian entrepreneur's function in each function played by a civil engineer in the evolved managerial role, the suitability of the evolved civil engineer's managerial role to be re-imagined as an entrepreneurial function can be determined. Table 3 shows the identification of the Marshallian entrepreneur's function in the evolved civil engineer's managerial role.

The assessment on the evolved civil engineer's managerial role by considering every function in the managerial role shows that, every function exhibits at least two elements of Marshallian entrepreneur's function. The element of establishing the general production plan or to decide on the optimal combination of the production factors is the dominant element of Marshallian entrepreneur's function as it can be found in every function. This clearly suggests that, in the evolved managerial role, the element of establishing the general production plan or to decide on the optimal combination of the production factors is possibly the core element in each function. Besides that, the assessment on the evolved civil engineer's managerial role also shows that, the function of a strategist or entrepreneur exhibits almost all of the elements of Marshallian entrepreneur's function. This potentially indicates a function in the evolved managerial role that can offer opportunity for civil engineers to embrace entrepreneurial orientation. Other functions in the evolved managerial role such as the role as a production engineer and manager, exhibits similar elements of Marshallian entrepreneur's function while the function of the technology innovator exhibits only the deciding what product to produce to satisfy human needs and the element of establishing the general production plan or to decide on the optimal combination of the production factors. As each function in the evolved managerial role exhibits at least one element of Marshallian entrepreneur's function, therefore the evolved civil engineer's managerial role can be deemed as the suitable managerial role to be re-imagined as an entrepreneurial function.

In retrospect of the assessment between the conventional and evolved managerial role, it can be seen that the presence of the element of deciding what product to produce to satisfy human needs differentiate the 2 types of managerial role. Hence, in order to reimagine a civil engineer's managerial role as an entrepreneurial function, the element of deciding what product to produce to satisfy human needs should not be absent from a civil engineer's managerial role. The elements of deciding what product to produce to satisfy human needs is an important element because satisfying human needs is an important contributor 
to successful innovations (Fayolle, 2007). Innovation in turn, will result in overcoming business competitions as innovations have been recognised as an important factor in winning business competitions (Distanont and Khongmalai, 2018). Thus, deciding what product to produce to satisfy human needs especially associated with a construction project is an opportunity to outperform competitors for construction enterprises and it is possible that it has not been considered in the production system of a construction project. On this note, it should be understood that human needs in this aspect is not only limited to human needs presented by clients but it possibly includes human needs by others involved in the project.

Therefore, to leverage on this opportunity, the ability to function as a strategist or an entrepreneur as highlighted in the evolved managerial role of a civil engineer is very crucial as there are various human needs needed to be fulfilled. In this condition, opportunity to embrace entrepreneurial orientation will present itself as the civil engineer who plays the managerial role will need to consider both internal and external factors which require the application of strategic orientation that includes decision-making processes, methods, and practices as highlighted by Wiklund and Shepherd (2005). This clearly suggests that, the civil engineers who play the managerial role (which can be re-imagined as an entrepreneurial function) will need to understand and explore different aspects of meeting human needs which are significant to a construction project. Thus, as the evolved civil engineer's managerial role exhibits the element of deciding what product to produce to satisfy human needs which is absent in the conventional civil engineer managerial role, in this paper, the evolved civil engineer's managerial role can be considered as the epitome of an entrepreneurial function in the production system of a construction project and it is a managerial role re-imagined as an entrepreneurial function.

\section{Future Research for Future Civil Engineering Practices}

Re-imagining civil engineer's managerial role as an entrepreneurial function highlights an area that is yet to be fully understood which is the element of deciding what product to produce to satisfy human needs. The challenge of meeting human needs in civil engineering practice is possibly in terms of determining which human needs should be considered as significant to a construction project as various parties involved in the project may present various needs. This requires careful considerations and unfortunately, analytical and systematic methods in deciding which human need is significant according to the authors' knowledge are still unavailable. As a consequence, factors that can contribute to innovation in construction projects remain unexplored and underutilised. Thus, future research that produces analytical and systematic methods in deciding significant human need in a construction project is important and crucial in turning a civil engineer's managerial role into an entrepreneurial function in the production system of a construction project.

\section{Future Research in Civil Engineering Education}

In view of the importance of entrepreneurial orientation in order to function as a strategist or an entrepreneur as demonstrated in the evolved civil engineer's managerial role, it can be seen that there is a need for civil engineering educators to introduce the elements of entrepreneurial orientation to civil engineering students. This will prepare future civil engineering graduates to be alert and sensitive to internal and external factors that are important in construction projects and to be able to analyse these factors in their decision making process. In order to introduce elements of entrepreneurial orientation without adding new subjects to civil engineering courses, civil engineering educators may need to discover experiential learning approach that can be integrated into existing courses or projects.

\section{Conclusions}

In retrospect of the discussion of re-imagining the managerial role as an entrepreneurial function, it can be seen that the element of deciding what product to produce to satisfy human needs is an important element that differentiate a managerial role that exhibits all elements of Marshallian entrepreneur's function from the conventional managerial role that exhibits less elements of Marshallian entrepreneur's function. Such managerial role that exhibits all elements of Marshallian entrepreneur's function presents opportunity to embrace entrepreneurial orientation as entrepreneurial aspects of decision-making styles, methods, and practices are needed in considering the internal and external factors of a construction project especially factors related to satisfying human needs. Therefore, for a civil engineer's managerial role to find opportunity to embrace entrepreneurial orientation and to be re-imagined as an entrepreneurial function in the production system of a construction project, the managerial role should not lack of the element of deciding what product to produce to satisfy human needs. As the element of deciding what product to produce to satisfy human needs in the context of the production system of a construction project is yet to be fully understood, future research in both civil engineering practices and civil engineering education is needed and crucial. 


\section{Acknowledgements}

We are very grateful to experts for their appropriate and constructive suggestions for this paper.

\section{REFERENCES}

[1] Abd-Hamid, Z., Azizan, N. A., and Sorooshian, S. (2015), Predictors for the Success and Survival of Entrepreneurs in the Construction Industry, International Journal of Engineering Business Management, 7(12), pp.1-11

[2] Anderson, S.D. (1992), Project Quality and Project Managers, International Journal of Project Management, 10 (3), pp.138-144

[3] Berglund, E.Z., Monroe, J.G., Ahmed, I., Noghabaei, M., Do, J., Pesantez, J.E., Fasaee, M.A.K., Bardaka, E., Han, K., Proestos G.T., and Levis, J, (2020), Smart Infrastructure: A Vision for the Role of the Civil Engineering Profession in Smart Cities, Journal of Infrastructure System, 26(2), pp1-32

[4] Blayse, A.M. and Manley, K. (2004), Key influences on construction innovation. Construction Innovation, 4 (1), pp143-154

[5]Entika, C.L., Jabor, M.K., Mohammad, S., and Osman, S. (2017), Defining the Meaning of Entrepreneurship Education for Future Engineering Graduates, Proceedings - 2017 7th World Engineering Education Forum (WEEF), 290-293

[6] Chan, A. P.C., and Chan A.P.L. (2004), Key Performance Indicators for Measuring Construction Success, Benchmarking: An International Journal, 11(2), pp203-221, Emerald Group Publishing Limited.

[7] Corotis, R.B., and Scanlan R.H., (1989), Future Of Civil Engineering Profession And Role Of Education, Journal of Professional Issues in Engineering, 115(2), pp.117-124

[8] Cuevas, J. G. (1994), Towards a Taxonomy of Entrepreneurial Theories, International Small Business Journal, 12(4), pp.77-88, SAGE Social Science Collections

[9] Dess, G.G and Lumpkin G.T (2005), The Role of Entrepreneurial Orientation in Stimulating Effective Corporate Entrepreneurship, Academy of Management Executive, 19(1), pp147-156

[10] Distanont, A. and Khongmalai, O.(2018), The role of innovation in creating a competitive advantage, Kasetsart Journal of Social Sciences, pp1-7

[11] Edum-Fotwe, F.T., and McCaffer, R., (2000), Developing project management competency: perspectives from the construction industry, International Journal of Project Management, 18(2), pp.111-124

[12] Fayolle, A., (2007), New Value Creation Dimension in the I <-> NVC Dialogic. Entrepreneurship And New Value Creation, The Dynamic of the Entrepreneurial Process, (pp.99-117). The Edinburgh Building, Cambridge CB2 8RU,
UK: Cambridge University Press.

[13] Fell (1990), Engineering Geophysics — A Civil Engineer's Veiwpoint Downloaded, Exploration Geophysics, 21(1), pp25-31

[14] Gambatese, J.A., Behm, M., and Rajendran, S., (2008), Design'rs role in construction accident causality and prevention: Perspectives from an expert panel, Safety Science, 46(1), pp675-691

[15] Goh, Y.M., and Chua, S., (2015), Knowledge, attitude and practices for design for safety: A study on civil \& structural engineers, Analysis and Prevention, 93(1), pp.260-266

[16] Grigg, N.S., Criswell, M.E., Fontane, D.G., and Siller, T.J., (2001), Civil Engineering Practice in the Twenty-First Century, Knowledge and Skill for Design and Management, (1st ed.) 1801 Alexander Bell Drive Reston, Virginia 2019-4400, American Society of Civil Engineers (ASCE) Press

[17] Head, P. (2009), Entering an ecological age: Entering an ecological age: the engineer's role, Proceeding of Institution of Civil Engineer, 162(CE2), pp.70-75

[18] Hensen, K.L. and Zenobia, K.E. (2011), Civil Engineer's Handbook of Professional Practice, $1^{\text {st }}$ Ed., New Jersey, US: John Wiley \& Sons

[19] Hodgson, M., Paton, S., and Cicmil, S., (2011), Great Expectations and Hard Times: The Paradoxical Experience of the Engineer as Project Manager, International Journal of Project Management, 29(1), pp374-382, Elsevier Ltd

[20] Hoften, J.D.A.V., (1988), A Civil Engineer's View From Space, Journal of Aerospace Engineer, 1(1), pp.28-34

[21] Karayiannis A. D. (2009), The Marshallian Entrepreneur, Historic of Economic Ideas, 17(3), pp.75-102, Accademia Editoriale

[22] Lyes, R.W., (1984), Planning Education: Desirable for Civil Engineers?, Journal of Urban Planning and Development, 110(1), pp.22-33

[23] Perez, A.I., and Ardaman, A.K. (1988), New Infrastructure: Civil Engineer's Mole, Journal of Urban Planning and Development,, 114 (2), pp.61-72

[24] Rogers, C.D.F., Hunt, D.V.L., Leach, J.M., Purnell, P., and Roelich K.E., (2017), Briefing: Resource scarcity and resource security - a suppressed civil engineering challenge, Proceedings of the Institution of Civil Engineers Waste and Resource Management 170 (WR2), pp.49-52

[25] Stokey, N. L. (2001), A Quantitative Model of the British Industrial Revolution 1780-1850, Carmegie-Rochester Conference Series of Public Policy 55, North-Holland, pp55-109, Elsevier Science B.V.

[26] Toole, T.M., (2005), Increasing Engineers' Role in Construction Safety: Opportunities and Barriers, Journal of Professional Issues in Engineering Education and Practice, 131(1), pp199-207

[27] Van Praag, C. M. (1999), Some Classic Views on Entrepreneurship, De Economist, 147(3), pp.311-355,Kluwer Academic Publishers 
[28] Vecenia, J.M., (2007), Entrepreneurship as a Scientific Research Programme, Álvaro Cuervo, Domingo Ribeiro, Salvador Roig (Eds.). Entrepreneurship, Concepts, Theory and Perspective, pp.23-71, Berlin, Germany: Springer-Verlag Berlin Heidelberg

[29] Watts, J.H., (2009), Allowed into a Man’s World’ Meanings of Work-Life Balance: Perspectives of Women Civil Engineers as 'Minority' Workers in Construction, Gender,
Work and Organization, 16(1), pp.37-57

[30] Wiklund, J., and Shepherd, D. (2005), Entrepreneurial Orientation and Small Business Performance a Configurational Approach, Journal of Business Venturing, 20(1), pp.71-91 